\title{
The DNA Comet Assay for Evaluating Damage to Leukocyte DNA after Photodynamic Therapy
}

\author{
DOI: 10.17691/stm2017.9.4.11
}

Received May 24, 2017

I.A. Chernigina, Head of the Laboratory of Molecular Biology, Department of Biology;

E.S. Plekhanova, Head of the Training Laboratory, Department of Biology;

T.G. Scherbatyuk, DSc, Professor, Head of the Department of Biology

Nizhny Novgorod State Medical Academy, 10/1 Minin and Pozharsky Square, Nizhny Novgorod, 603005, Russian Federation

The aim of this research was (by using the DNA comet method) to study the level of DNA damage in leukocytes of the whole blood in tumor-bearing animals after photodynamic therapy (PDT) with the local administration of a photosensitizer.

Materials and Methods. The experiments were performed on 30 non-linear male albino rats. As a model of neoplasia, the rat renal carcinoma strain was used. The animals were divided into three groups: intact $(n=10)$, without exposure $(n=10)$ and with PDT exposure $(n=10)$; each group was then divided into two subgroups according to the initial tumor volume: $A-$ less than $0.3 \mathrm{~cm}^{3}$ and $B-$ more than $0.5 \mathrm{~cm}^{3}$.

In the PDT group, $0.3 \%$ Photosens (SRC "NIOPIK", Russia) was injected into the tumor. Then, $6-12 \mathrm{~h}$ after the injection, the tumor area was irradiated with a LED laser beam $\left(\lambda=660 \pm 10 \mathrm{~nm}, P=100 \mathrm{~mW} / \mathrm{cm}^{2}\right)$. The PDT sessions were conducted on the $15^{\text {th }}$ and $19^{\text {th }}$ day after the transplantation.

The antitumor effect was evaluated by the absolute tumor growth rate. The DNA damage was assessed by the DNA comet assay adapted for this study. The \%TDNA - the relative DNA content of the comet tail — was used for quantification.

Results. A direct correlation between the DNA damage and the absolute tumor growth was found (Spearman rank correlation coefficient $r_{s}=0.85 ; p=0.006$ ). Using the DNA comet method we observed an increased DNA damage in leukocytes of tumor-bearing animals exposed to PDT in the subgroup with initial tumor volumes $<0.3 \mathrm{~cm}^{3}$; whereas no such changes were found in the subgroup with tumors $>0.5 \mathrm{~cm}^{3}$. When PDT was preceded by a Photosens injection, the tumors regressed in $50 \%$ of rats regardless of the initial tumor volume. In rats resistant to PDT, the tumor growth was stimulated in rats with the initial tumors $<0.3 \mathrm{~cm}^{3}$.

Conclusion. The level of DNA damage in blood leukocytes, determined with the alkaline version of the DNA comet method after author's modification, can be used to indirectly evaluate the growth rate of a malignant neoplasm and predict the tumor response to photodynamic therapy combined with a locally-administered photosensitizer.

Key words: photodynamic therapy; Photosens; DNA comet assay; DNA damage.

Photodynamic therapy (PDT) is used for the treatment of oncological diseases of the skin [1-3], esophagus [4, 5], lungs [6-8], nervous system [9, 10], female reproductive organs [11-13], and the biliary tract [14], as well as head and neck tumors [15-17]. In practice, PDT can be used as an independent modality and in combined therapy or palliative care. However, there are a number of restrictions, such as insufficient singlet oxygen generation [18], a small depth of PDT penetration into a biotissue [19], and skin phototoxicity [20]; these limitations prevent the PDT from a broader clinical use.

Local (interstitial) photosensitizers (PS) administered directly into the tumor tissue, help avoid photodermatosis, can prevent PS accumulation in organs with high metabolic activity, allow increasing PS concentration in the tumor without enhancing skin phototoxicity, and reduce treatment costs. The PDT technique combined with the local administration of Russia-made PS into a tumor has been under development at the Medical Research Center of Radiology, Russian Academy of Medical Sciences since 2000 [21-23].

It is known that the combination of PDT with PS generates the active forms of oxygen, especially singlet oxygen, which has cytotoxic and mutagenic effects on cellular organelles and DNA molecules [24-26].

Back in 1997, using various tumor cell cultures, McNair et al. [27] showed that the "alkaline" version of the DNA comet assay can be used to effectively screen the cells for DNA damage caused by laser therapy at different wavelengths. However, this approach found its use in clinical practice only by Haylett et al. [28] and Mozaffarieh et al. [29].

In this study, the DNA comet assay is proposed to evaluate the damage to the leukocytes DNA in animals with experimental neoplasia after PDT with local administration of PS.

The aim of the study was, by using the DNA

For contacts: Tatyana G. Scherbatyuk, e-mail: ozone_stg@mail.ru 
comet method, to evaluate the level of DNA damage in whole blood leukocytes of tumor-bearing animals after photodynamic therapy with local administration of a photosensitizer.

In the process of the work, the following issues were addressed:

to estimate the level of DNA damage in whole blood leukocytes in rats with a growing tumor of renal carcinoma;

to evaluate the DNA damage in whole blood leukocytes of the tumor-bearing rats after photodynamic therapy with local administration of PS.

Materials and Methods. The experiments were performed on 30 outbred Sprague Dawley rats (males) weighing $250 \pm 25 \mathrm{~g}$ at the Department of Biology of the Nizhny Novgorod State Medical Academy. The animals were purchased from the Pushchino breeding farm and were kept under the standard animal house conditions: they received a full-feed diet (Laboratorkorm, Moscow) and tap water ad libitum.

The rats were withdrawn from the experiment by decapitation under anesthesia, all manipulations were carried out in full accordance with the ethical principles of the European Convention for the Protection of Vertebrate Animals used for Experimental and Other Scientific Purposes (adopted in Strasbourg on 18.03.1986 and confirmed in Strasbourg on 15.06.2006), as well as in accordance with the guidelines specified in the Guide for the Care and Use of Laboratory Animals (National Research Council, 2011). The work was approved by the Ethics Committee of the Nizhny Novgorod State Medical Academy.

Since the photodynamic impact is most effective in the superficially localized tumors (and no transplantable strain of rat melanoma was available), we used the neoplasia model of renal carcinoma (PA) transplanted by subcutaneous inoculation of the tumor material. Initially, this solid tumor was produced by injecting 6-methylthiouracil to castrated rats; this original strain has been stored in the Bank of tumor strains at the N.N. Blokhin Russian Cancer Research Center, Russian Academy of Medical Sciences. This tumor grows fast with a relatively short incubation period, not exceeding 7-10 days; the tumor development is fully completed within 26 days after transplantation. Carcinoma PA is characterized by a sufficiently large biomass and a high degree of successful transplantation [30].

On the $9^{\text {th }}$ day after the tumor transplantation, when the renal carcinoma reached a controlled size $\left(0.07-4.20 \mathrm{~cm}^{3}\right)$, the animals were divided into three experimental groups: 1) intact - healthy rats $(n=10)$; 2) without exposure - tumor-bearing rats with no treatment $(n=10) ; 3)$ PDT - tumor-bearing rats exposed to PDT $(n=10)$. To reach a greater intragroup homogeneity, the behavioral characteristics of the rats determined with the open field test were taken into consideration [31]. After the animals were grouped, the tumor growth was monitored for 5 days.
In studies on PDT [20], tumors of different sizes showed different responses to PDT. With this in mind, we introduced an additional sub-division in each of the 3 main groups. Thus, subgroup A included animals with the initial tumor volumes up to $0.3 \mathrm{~cm}^{3}$ and subgroup $\mathrm{B}$ - with initial tumor volumes greater than $0.5 \mathrm{~cm}^{3}$.

To carry out a photodynamic session, we used a second generation synthetic PS - hydroxyaluminum trisulfophthalocyanine (Photosens) (NIOPIK, Russia), which had an absorption peak within the spectral region of biotissue transparency (at $676 \mathrm{~nm}$ ); that allowed targeting deeper layers of the tumor tissue. The PS was administered into the tumor tissue, using the local (interstitial) approach [21-23]. Here, $0.3 \%$ solution of the PS was injected into the tumor at three points. Then, 6-12 h later, each injection point was irradiated with a LED laser beam at a wavelength of $660 \pm 10 \mathrm{~nm}$ and a radiation power density of $100 \mathrm{~mW} / \mathrm{cm}^{2}$ (energy density of $60 \mathrm{~J} / \mathrm{cm}^{2}$ ). Each exposure lasted for $10 \mathrm{~min}$. The radiation parameters were in accordance with the instruction for PS use. As a light source, a physiotherapeutic light-emitting diode AFS (Polironik, Russia) was used. A total of two PDT sessions were performed on the $15^{\text {th }}$ and $19^{\text {th }}$ day after the tumor transplantation; that was the period of active growth of renal carcinoma in rats. The tumor volume was measured on the $10^{\text {th }}$ and $20^{\text {th }}$ day after transplantation, i.e. 5 days before the first PDT session and one day after the second PDT session took place. Anesthetized animals were withdrawn from the experiment on the $20^{\text {th }}$ day by decapitation.

The antitumor effect of PDT was assessed by a coefficient $K$ reflecting the absolute increase in the tumor volume $V$, which was calculated by the formula:

$$
K=\frac{V_{t}-V_{0}}{V_{0}} ; V=\frac{\pi}{6}\left(\frac{d_{1}+d_{2}}{2}\right)^{3},
$$

where: $d_{1}$ and $d_{2}$ are two mutually perpendicular cross sections of the tumor $(\mathrm{cm}) ; V_{o}$ is the tumor volume before exposure $\left(\mathrm{cm}^{3}\right) ; V_{t}$ is the tumor volume on a given day $\left(\mathrm{cm}^{3}\right)$ [22].

The range of values $K>0$ corresponded to continued tumor growth, values $-1<\mathrm{K}<0$ were viewed as growth inhibition and $\mathrm{K}=-1$ indicated a complete tumor regression. The conclusion about complete regression of neoplasia was made in the absence of a visible and palpable focus [22].

The quantification of the DNA damage in whole blood leukocytes was carried out according to the DNA comet protocol [32].

Images of DNA comets were photographed mainly in the central part of the slides, where the comets were located in the same plane.

The pictures were taken with a digital camera, model DS-Fi2 (Nikon Corporation, Japan) connected to a direct microscope Nikon Eclipse Ni-U (Nikon Corporation, Japan). The obtained images were processed with the help of the Comet.exe software, developed specifically 
for image analysis (Stepanov [33]). One hundred comets per slide were viewed and the results were averaged for each experimental point. To quantify the DNA damage, we used the term \%TDNA, which reflected the relative DNA content in the comet "tail" and calculated as the \% ratio of the fluorescence signal in the comet "tail" to the total fluorescence signal in the entire comet [34]. In total, 60 slides were viewed in the experiment.

Since the obtained data did not obey the normal distribution, the median $(\mathrm{Me})$ and the interpercentile range (Me $[25 \%, 75 \%]$ ) were used for data presentation; accordingly, the data was processed using nonparametric statistics methods, specifically the MannWhitney $U$ test and the Spearman rank correlation. The data was processed using Microsoft Office Excel, Statistica 8.0 and AtteStat software packages.

Results and Discussion. Parameters of the tumor growth before and after the photodynamic therapy are presented in Table 1.

In the tumor-bearing animals not treated with PDT, no spontaneous regression of carcinoma was detected. The coefficient of absolute tumor growth in subgroup B with initially larger volumes of neoplasia was significantly higher than that in subgroup A with initially smaller tumors, i.e., 7.57 [3.57; 11.63] and 1.29 [1.20; 1.37] $(p=0.011)$. At the same time, the level of spontaneous DNA damage in whole blood leukocytes from subgroup $B$ (\%TDNA) was 2 -fold higher than that in subgroup A, i.e., 5.65 [3.55; 6.95] and 2.45 [2.36; 2.75], respectively $(p=0.044)$. The relation between the carcinoma growth and DNA damage in nucleated blood cells was confirmed by a correlation analysis, namely: a direct relationship was found between the tumor growth rate and the level of spontaneous DNA damage $\left(r_{s}=0.85, p=0.006\right)$.

We observed and described specific morphological differences between the comets formed from the blood cell DNA of intact rats versus tumor-bearing rats (Figure 1). Thus, the nucleoids of blood cells from intact rats or rats with initially smaller tumors (subgroup A) looked as bright symmetrical DNA spheres (Figure 1 (a), (b)). In contrast, the nucleoids from blood cell of rats with initially large tumors (subgroup B) were asymmetrical and formed a short "tail" of damaged DNA fragments when run in agarose gel (Figure 1 (c)).

Table 1

Growth of carcinoma of PA rats after photodynamic therapy (PDT) (Me [25\%; 75\%])

\begin{tabular}{|c|c|c|c|c|c|c|}
\hline \multirow{2}{*}{ Group } & \multirow{2}{*}{$\begin{array}{l}\text { Initial tumor } \\
\text { volume }\left(\mathrm{cm}^{3}\right)\end{array}$} & \multicolumn{2}{|c|}{ Tumor volume after transplantation $\left(\mathrm{cm}^{3}\right)$} & \multirow{2}{*}{$\begin{array}{c}\text { Tumor } \\
\text { regression }(\%)\end{array}$} & \multirow{2}{*}{$\begin{array}{l}\text { Coefficient } \\
\text { of tumor growth }\end{array}$} & \multirow{2}{*}{$\%$ TDNA } \\
\hline & & Day 10 (before PDT) & Day 20 (after PDT) & & & \\
\hline \multicolumn{7}{|l|}{ No PDT: } \\
\hline subgroup $A(n=4)$ & $0.07-0.22$ & $0.15[0.07 ; 0.22]$ & $0.33[0.14 ; 0.52]$ & 0 & $1.29[1.20 ; 1.37]$ & $2.45[2.36 ; 2.75]$ \\
\hline subgroup $B(n=6)$ & $0.52-4.19$ & $1.40[1.02 ; 2.81]$ & $20.83[4.68 ; 35.43]$ & 0 & $7.57[3.57 ; 11.63]^{*}$ & $5.65[3.55 ; 6.95]^{*}$ \\
\hline \multicolumn{7}{|l|}{ PDT: } \\
\hline subgroup $A(n=4)$ & $0.07-0.22$ & $0.07[0.07 ; 0.15]$ & $0.23[0.0 ; 16.98]$ & 50 & $2.21[-1 ; 78.06]$ & $7.91[5.50 ; 10.02]^{*}$ \\
\hline subgroup $B(n=6)$ & $0.52-4.19$ & $1.77[1.77 ; 2.57]$ & $12.22[0.0 ; 33.27]$ & 50 & $1.92[-1 ; 17.26]$ & $4.20[3.10 ; 6.0]$ \\
\hline Intact $(n=10)$ & - & - & - & - & - & $3.72[2.72 ; 3.80]$ \\
\hline
\end{tabular}

* $p<0.05$ in comparison with the "no PDT" group with initially small tumors, the Mann-Whitney U test.
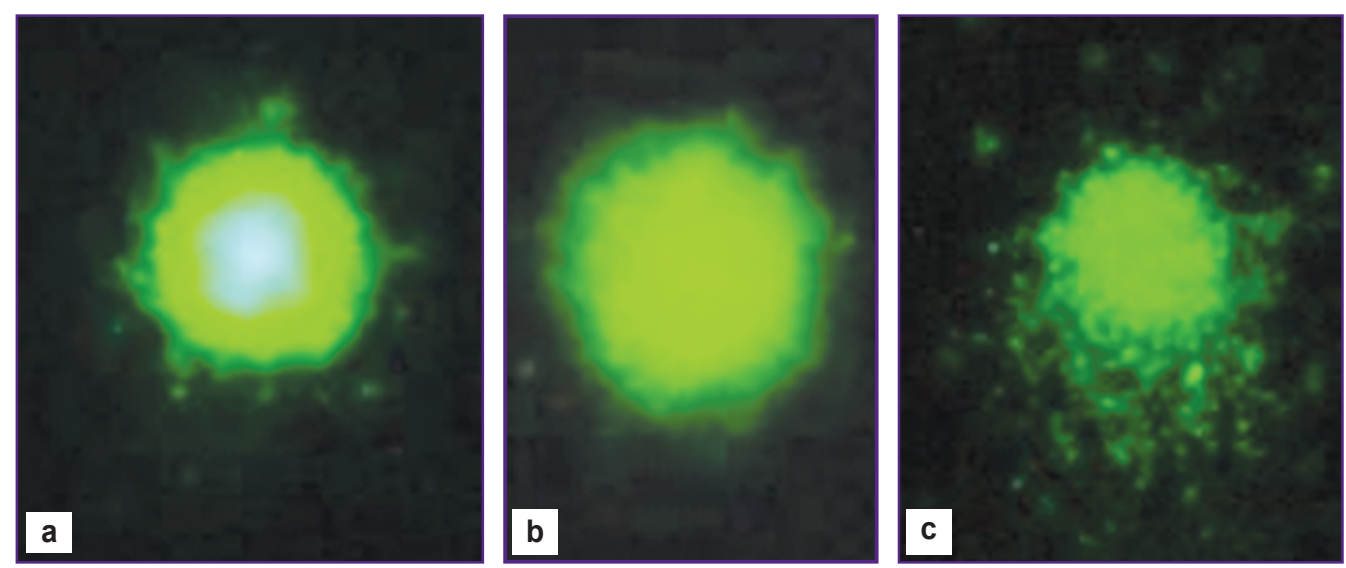

Figure 1. Microphotographs of the blood cell nucleoid:

(a) intact rats; \%TDNA=3.72 [2.72; 3.80]; ×200; (b) rats from the "no PDT" group, subgroup A; $\%$ TDNA=2.45 [2.36; 2.75]; ×200; (c) rats from the "no PDT" group, subgroup B; \%TDNA=5.65 [3.55; $6.95] ; \times 200$ 
Table 2

The growth rate of renal carcinoma in rats resistant to photodynamic effect (PDT) (Me [25\%; 75\%])

\begin{tabular}{lccc}
\hline Group & Subgroup & $\begin{array}{c}\text { Number of rats with zero } \\
\text { tumor regression }\end{array}$ & $\begin{array}{c}\text { Coefficient } \\
\text { of tumor growth }\end{array}$ \\
\hline No PDT & A & 4 & $1.28[1.20 ; 1.37]$ \\
\hline \multirow{2}{*}{ PDT } & B & 6 & $7.56[3.57 ; 11.63]$ \\
\hline
\end{tabular}
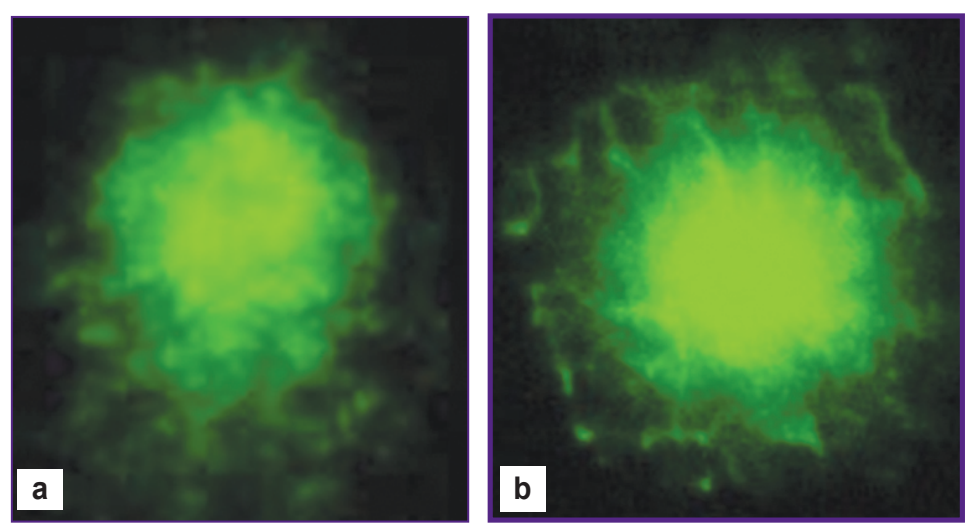

Figure 2. Microphotograph of the blood cell nucleoid after photodynamic therapy:

(a) in subgroup $A$; \%TDNA=7.91 [5.50; 10.02]; ×200; (b) in subgroup $B$; $\%$ TDNA $=4.20[3.10 ; 6.00] ; \times 200$

When a PDT session was preceded by a local administration of the Photosens agent, complete regression of transplanted neoplasia $(K=-1)$ was observed in $50 \%$ of tumor-bearing rats regardless of initial tumor size (see Table 1). These results are comparable with those of others who observed regression of experimental M-1 sarcoma after PDT with a local administration of Photoditazine [22].

However, when comparing the tumor growth rates in animals without therapy and after photodynamic exposure, there were no significant differences between the rats with initially large and with initially small tumor sizes. This can be explained by the fact that in animals that remained resistant to photodynamic action (2 cases out of 4 in subgroup $A$ and 3 out of 6 in subgroup B), there was a greater carcinoma growth in the initially small and a mild growth in the initially large tumors as compared with tumor-bearing animals without PDT (Table 2).

Thus, we found an individual response to PDT (regression of neoplasia or stimulation of its growth) in rats with transplanted renal carcinoma; this type of response did not depend on the initial tumor size.

After the photodynamic exposure, the level of spontaneous DNA damage in leukocytes of rats with initially small tumors increased 3-fold compared to animals without therapy $(p=0.021)$ but did not change in animals with initially large tumor volumes (see Table 1).

According to the morphology analysis, the DNA material from blood of tumor-bearing animals exposed to PDT showed marked polymorphism of the resulting DNA comets (Figure 2).

After PDT sessions, the comets in subgroup A showed a well-defined "tail" consisting of fluorescent fragments of the damaged DNA (Figure 2 (a)). However, in subgroup B there were no such fluorescent "tails", but only a halo of damaged DNA around the central focus (Figure 2 (b)).

Summing up, the following results were obtained in this study.

A direct correlation between the level of spontaneous DNA damage and the absolute coefficient of tumor growth $\left(r_{s}=0.85, p=0.006\right)$ was found.

After PDT sessions, we detected an increased level of spontaneous DNA damage in whole blood leukocytes of tumor-bearing animals with the initial carcinoma volumes $<0.3 \mathrm{~cm}^{3}$; no changes were found in the group with the initial tumor volumes $>0.5 \mathrm{~cm}^{3}$. Obviously, the increased level of basal DNA damage can serve as a predictive parameter for the PDT induced biological effect.

We found that photodynamic therapy with the local administration of Photosens led to regression of carcinoma regardless of the initial tumor size in $50 \%$ of tumor-bearing rats.

In rats resistant to PDT and having tumors of an initial volume $<0.3 \mathrm{~cm}^{3}$, the tumor growth accelerated.

Conclusion. The level of DNA damage in blood leukocytes detected with the alkaline version of the DNA comet assay in the author's modification can be used to indirectly estimate the growth rate of a malignant neoplasm and predict the tumor response to photodynamic therapy combined with a local administration of a photosensitizer.

Acknowledgments. The authors express their gratitude to DSc, Professor G.S. Terentyuk and DSc A.B. Bucharsky for their generous contribution to this report.

Financial Support and Conflicts of Interest. The study was not supported by any external source, and there are no conflicts of interest related to this study.

\section{References}

1. Kaplan M.A., Kapinus V.N., Popuchiev V.V., Romanko Yu.S., Yaroslavtseva-Isaeva E.V., Spichenkova I.S., Shubina A.M., Borgul O.V., Goranskaya E.V. Photodynamic therapy: results and prospects. Radiatsiya i risk (Byulleten' NRER) 2013; 22(3): 115-123.

2. Gamayunov S.V., Grebenkina E.V., Ermilina A.A., 
Karov V.A., König K., Korchagina K.S., Skrebtsova R.R., Terekhov V.M., Terentiev I.G., Turchin I.V., Shakhova N.M. Fluorescent monitoring of photodynamic therapy for skin cancer in clinical practice. Sovremennye tehnologii v medicine 2015; 7(2): 75-83, https://doi.org/10.17691/stm2015.7.2.10.

3. Fargnoli M.C., Peris K. Photodynamic therapy for basal cell carcinoma. Future Oncol 2015; 11(22): 2991-2996, https:// doi.org/10.2217/fon.15.208.

4. Duvanskiy V.A., Knyazev M.V., Pravednikov P.V. Modern aspects of photodynamic therapy of esophageal. Eksperimental'naya i klinicheskaya gastroenterologiya 2011; 10: 111-116.

5. Yi E., Yang C.K., Leem C., Park Y., Chang J.E., Cho S., Jheon S. Clinical outcome of photodynamic therapy in esophageal squamous cell carcinoma. $J$ Photochem Photobiol B 2014; 141: 20-25, https://doi.org/10.1016/j. jphotobiol.2014.09.001.

6. Yaitsky N.A., Gerasin V.A., Orlov S.V., Butenko A.B., Molodtsova V.P., Derevyanko A.V., Stelmakh L.V., Urtenova M.A., Gerasin A.V. Photodynamic therapy in treatment of lung cancer. Vestnik khirurgii im. I.I. Grekova 2010; 169(5): 31-34.

7. Simone C.B. 2nd, Cengel K.A. Photodynamic therapy for lung cancer and malignant pleural mesothelioma. Semin Oncol 2014; 41(6): 820-830, https://doi.org/10.1053/j. seminoncol.2014.09.017.

8. Chen K.C., Hsieh Y.S., Tseng Y.F., Shieh M.J., Chen J.S., Lai H.S., Lee J.M. Pleural photodynamic therapy and surgery in lung cancer and thymoma patients with pleural spread. PLoS One 2015; 10(7): e0133230, https://doi. org/10.1371/journal.pone.0133230.

9. Kubasova I.Yu., Vakulovskaya E.G., Ermakova K.V., Smirnova Z.S. Fluorescent detection and photodynamic therapy in treatment of brain tumors. Rossiyskiy bioterapevticheskiy zhurnal 2006; 5(4): 54-63.

10. Uzdensky A.B., Berezhnaya E., Kovaleva V., Neginskaya M., Rudkovskii M., Sharifulina S. Photodynamic therapy: a review of applications in neurooncology and neuropathology. J Biomed Opt 2015; 20(6): 61108, https://doi. org/10.1117/1.jbo.20.6.061108.

11. Trushina O.I., Chissov V.I., Sokolov V.V., Novikova Ye.G., Filonenko Ye.V., Frank G.A., Volchenko N.N. The antiviral and antitumor efficiency of photodynamic therapy in precancer and early cancer of the cervix uteri. Rossiyskiy onkologicheskiy zhurnal 2009; 4: 15-18.

12. Hillemanns P., Garcia F., Petry K.U., Dvorak V., Sadovsky O., Iversen O.E., Einstein M.H. A randomized study of hexaminolevulinate photodynamic therapy in patients with cervical intraepithelial neoplasia 1/2. Am J Obstet Gynecol 2015; 212(4): 465.e1-465.e7, https://doi.org/10.1016/j. ajog.2014.10.1107.

13. Krikunova L.I., Mkrtchyan L.S., Kaplan M.A., Rykova E.V., Kapinus V.N. Possibilities of photodynamic therapy for vulvar cancer. Radiatsiya $i$ risk (Byulleten' NRER) 2015; 24(2): 107-115.

14. Patel J., Rizk N., Kahaleh M. Role of photodynamic therapy and intraductal radiofrequency ablation in cholangiocarcinoma. Best Pract Res Clin Gastroenterol 2015; 29(2): 309-318, https://doi.org/10.1016/j.bpg.2015.02.008.

15. Stranadko E.P., Titova V.A., Riabov M.V., Petrovsky V.Y. Photodynamic therapy as a component of combined and complex treatment of head and neck cancer. Al'manakh klinicheskoy meditsiny 2006; 12: 37.
16. Ulupov M.J. A method for interstitial photodynamic treatment of head and neck malignancies. Rossiyskaya otorinolaringologiya 2010; 1(44): 137-140.

17. Polkin V.V., Kaplan M.A., Medvedev V.S., Semin D.Yu., Kapinus V.N., Spichenkova I.S., Isayev P.A., Derbugov D.N., Shubina A.M. Place of photodynamic therapy in organ-sparing treatment programs for squamous cell carcinoma of the oral mucosa. Opukholi golovy i shei 2012; 1: 23-28.

18. Mironov A.F. Photodynamic cancer therapy: a novel effective method for the malignant tumors diagnostics and treatment. Sorosovskiy obrazovatel'nyy zhurnal 1996; 8: 32-40.

19. Meerovich I.G., Meerovich G.A., Oborotova N.A., Baryshnikov A.Yu. Distribution of light along the depth of the tumor lesion and efficiency of utilization of therapeutic irradiation during the photodynamic therapy. Rossiyskiy bioterapevticheskiy zhurnal 2006; 5(3): 93-97.

20. Tsyb A.F., Kaplan M.A., Romanko Yu.S., Popuchiev V.V. Fotodinamicheskaya terapiya [Photodynamic therapy]. Moscow: Meditsinskoe informatsionnoe agentstvo; 2009; $212 \mathrm{p}$.

21. Lagoda T.S., Kaplan M.A., Krivosheev la.V., Zhavoronkov L.P., Bokova M.B. The optimization of a plan for the photodynamic therapy of sarcoma M1 using photosens. Voprosy onkologii 2000; 46(3): 327-331.

22. Yaroslavtseva-Isaeva E.V., Kaplan M.A., Romanko Ju.S., Sokol N.I. Method of photodynamic therapy of experimental tumor (sarcoma-MI) with local administration of photosensitizer. Rossiyskiy bioterapevticheskiy zhurnal 2003; 2(4): 19-22.

23. Lagoda T.S., Kaplan M.A., Bondar' A.M., Bokova M.B., Ivanov E.A., Brovin A.I., Spichenkova O.N. Use of photosense treatment to enhance photodynamic effect on solid sarcoma-1 in Wistar rats. Voprosy onkologii 2005; 51(1): 103-107.

24. Bonnet R., Berenbaum M. Porphyrins as photosensitizers. In: Photosensitising compounds: their chemistry, biology and clinical use. Bock G., Harnett S. (editors). John Wiley \& Sons, Chichester; 1989; p. 40-49.

25. Moan J., Berg K., Kvam E., Western A., Malik Z., Rock A., Schneckenburger $H$. Intracellular localization of photosensitizers. In: Ciba Foundation Symposium 146. Wiley, Chichester; 1989; p. 95-111.

26. Moan J. On the diffusion length of singlet oxygen in cells and tissues. J Photochem Photobiol B Biol 1990; 6: 343347, https://doi.org/10.1016/1011-1344(90)85104-5.

27. McNair F.I., Marples B., West C.M., Moore J.V. A comet assay of DNA damage and repair in K562 cells after photodynamic therapy using haematoporphyrin derivative, methylene blue and meso-tetrahydroxyphenylchlorin. $\mathrm{Br} J$ Cancer 1997; 75(12): 1721-1729, https://doi.org/10.1038/ bjc.1997.295.

28. Haylett A.K., Ward T.H., Moore J.V. DNA damage and repair in Gorlin syndrome and normal fibroblasts after aminolevulinic acid photodynamic therapy: a comet assay study. Photochem Photobiol 2003; 78(4): 337-341, https://doi. org/10.1562/0031-8655(2003)078<0337:ddarig>2.0.co;2.

29. Mozaffarieh M., Schötzau A., Josifova T., Flammer J. The effect of ranibizumab versus photodynamic therapy on DNA damage in patients with exudative macular degeneration. Mol Vis 2009; 15: 1194-1199.

30. Eksperimental'naya otsenka protivoopukholevykh preparatov $v$ SSSR $i$ SShA [Experimental evaluation of antitumor drugs in the USSR and USA]. Pod red. Sof'inoy Z.P., 
Syrkina A.B., Goldina A., Klyayna A. [Sof'ina Z.P., Syrkin A.B., Goldin A., Klyayn A. (editors)]. Moscow: Meditsina; 1980; 295 p.

31. Bures J., Bureshova O., Huston J.P. Metodiki i osnovnye eksperimenty po izucheniyu mozga i povedeniya [Techniques and basic experiments on the study of the brain and behavior]. Moscow: Vysshaya shkola; 1991; 399 p.

32. Chernigina I.A., Shcherbatyuk T.G. A new version of comet assay. Sovremennye tehnologii v medicine 2016; 8(1): 20-27, https://doi.org/10.17691/stm2016.8.1.03.
33. Stepanov V.N. Metody i programmnye sredstva avtomatizatsii analiza izobrazheniy mediko-biologicheskikh mikroob»ektov. Avtoref. dis. ... kand. tekhn. nauk [The techniques and software tools for automation of image analysis of biomedical micro-objects. PhD Thesis]. Moscow; 2005.

34. Sirota N.P., Kuznetsova E.A. The comet assay application in radiobiological investigations. Radiatsionnaya biologiya. Radioekologiya 2010; 50(3): 329-339. 